\title{
A Social and Food Survey of the Elderly, Living Alone or as Married Couples
}

\author{
BY E. R. BRANSBY \\ Ministry of Health, Savile Row, London, W. I \\ AND BARBARA OSBORNE \\ Government Social Survey, Montagu Mansions, Crawford Street, London, $W$. I
}

(Received 8 fuly 1952)

The present report relates to a social and food survey of the elderly in Sheffield which forms part of a health survey made under the aegis of Professor W. Hobson of the Department of Social and Industrial Medicine, University of Sheffield.

\section{Nature of sample surveyed}

\section{EXPERIMENTAL}

The subjects included in the health survey were among those studied previously by the Sheffield Council of Social Service in a survey of the social and economic circumstances of the elderly in Sheffield (Greenlees \& Adams, I950). The sample then used was drawn in March 1948 and was a $I$ in 30 random selection from the food-office register of women over 60 and men over 65 . The final sample studied by the Sheffield Council of Social Service consisted of I 77 I subjects. The health survey was restricted to those of the $177 \mathrm{I}$ subjects who were living alone or as married couples, that is, without any other person.

In the health survey, those eligible for inclusion were first interviewed by a sociologist who, in addition to getting certain sociological data, invited their co-operation in the health survey. Subjects who were willing were then medically examined in their homes, and the examination was followed, if they were willing, by dental, radiographical and ophthalmological examinations in hospital. The subjects were invited to co-operate in the social and food survey after completion of the medical examination at home. Of the $177 \mathrm{I}$ persons studied by the Sheffield Council of Social Service, 736 were eligible for inclusion in the health survey. Of these, I 8 were excluded because they had died or left Sheffield, or because their family circumstances had changed, and 142 refused the medical examination. There were thus 476 subjects available for the social and food survey; complete records were obtained from $303(64 \%)$. Table I gives the reasons why the $173(36 \%)$ subjects did not take part in the social and food survey. Analysis of the appropriate data for those who were included in the survey and for those who were excluded from it, shows that men and women were equally willing and able to keep the records, and that records were obtained from a higher proportion of the younger subjects and from those living as married couples than from the more elderly and those living alone. The fact that a subject was working does not appear to have influenced his or her co-operation. 
Analysis of the results of the health survey showed that those who were medically examined were rather more representative of those living in the poorer areas of Sheffield than those who were not medically examined, but the same was not true of those who completed the social and food survey.

Table r. Reasons for non-co-operation in the social and food survey of 173 out of 476 subjects who had taken part in a previous survey and completed a medical examination

\section{Reason}

Died since medical examination

Changed household status since medical examination or no longer living in Sheffield

Not able to co-operate because of type of job, e.g. commercial traveller

Not able to co-operate because of illness, deafness, bad eyesight or illiteracy

Willing to co-operate at first interview but refused at recall

Unwilling to be bothered or feeling unable to co-operate, including also some with whom the interviewer failed to get in touch after several recalls

Records incomplete

Percentage of total lost

Percentage of total with completed records

$\begin{array}{cc}\begin{array}{c}\text { Proportion of } \\ \text { Proportion of } \\ \text { total number } \\ \text { to })\end{array} & \begin{array}{c}\text { eligible to be } \\ \text { included in the } \\ \text { food survey } \\ (\%)\end{array} \\ 3 & 1 \\ 8 & 3 \\ 2 & - \\ 30 & 11 \\ 14 & 5 \\ 33 & 12 \\ & \\ \text { I0 } & \\ 36 & - \\ 64 & \end{array}$

\section{Procedure}

Collection of information. The information collected was of three kinds, on social and domestic circumstances, on economic circumstances and on food consumption. The study for all the subjects lasted I week. During the week the subject kept a record of all the food he or she ate (Widdowson, 1936; Beltram \& Bransby, 1950). A spring balance and standard tablespoons and teaspoons were provided for the purpose. The record related only to the selected subject, and not, if married, to the spouse. The subject or his wife was asked also to keep for the same week a record of the household expenditure on food, rent, drink, tobacco and fuel, and to provide information on earnings. Information was obtained also on the domestic circumstances of the household. During the survey week the subject was visited three or four times by a field worker to ensure that the records were being properly kept.

On the whole, the subjects co-operated well and were conscientious in following the instructions given by the field workers. Several who co-operated were suffering from severe disabilities; among them, for example, was a man whose fingers were badly twisted with arthritis; one woman's eyesight was so poor that she used a magnifying glass to read the scales; another woman was bedridden but her husband, in addition to doing all the housework, kept her records for her with little complaint.

The field work of the main survey took place during the period January I950-March I95 I, although the main survey was preceded by a pilot survey in October 1949. The field work was done by four experienced investigators, Miss J. Atkinson, Mrs M. Bell, Mrs N. B. Howell and Mrs G. Fawkes, of the Government Social Survey. 
The survey just described relates to the elderly living at home. Records of food consumption for I week were obtained also for eight men and eight women living in residential homes run by the Social Care Department of the City of Sheffield. All the food eaten by each of these subjects during I week was weighed. The information was collected by Miss J. B. Beveridge, Miss A. K. Chalmers and Mrs B. M. Needham.

In later sections of the present report, data on food consumption and on the intakes of calories and nutrients are presented for certain of the subjects graded as fit, and there are some observations on the intake of the less fit. The classification was made by Dr H. Droller, who made the medical examinations for the health survey referred to above.

Calculation of calories and nutrients. The calories and nutrients in the diets were calculated from the values given in Nutritive Values of Wartime Foods (Accessory Food Factors Committee, 1945) and in Chemical Composition of Foods (McCance \& Widdowson, 1946) and from recipes compiled in accordance with present food habits. The energy values have been calculated as recommended in Nutritive Values of Wartime Foods. The vitamin A and carotene values have been calculated in terms of preformed vitamin A, and an allowance has been made for the cooking losses of vitamins, both as recommended in Nutritive Values of Wartime Foods.

\section{RESULTS}

Elderly persons living at home

\section{Social and domestic circumstances}

Age and household composition. At the time the social and food survey was made the majority of the men were over 70 and of the women under 70 (Table 2).

Subjects living alone formed just under one-third of those completing the records. Most of the subjects living as married couples were themselves living with a husband or wife who was over 65 . In only $16 \%$ of the cases was the husband or wife under 65 .

Table 2. Proportions of the 303 men and women of different ages who were living alone or as married couples who completed the survey

\begin{tabular}{|c|c|c|c|c|c|c|c|c|c|}
\hline \multirow[b]{2}{*}{$\begin{array}{c}\text { Age } \\
\text { (years) }\end{array}$} & \multicolumn{3}{|c|}{ Proportion of men } & \multicolumn{3}{|c|}{ Proportion of women } & \multicolumn{2}{|c|}{$\begin{array}{l}\text { Proportion of } \\
\text { all old people }\end{array}$} & \multirow[b]{2}{*}{$\begin{array}{c}\text { Pro- } \\
\text { portion } \\
\text { of total } \\
(\%)\end{array}$} \\
\hline & $\begin{array}{l}\text { Living } \\
\text { alone } \\
(\%)\end{array}$ & $\begin{array}{c}\text { Living as } \\
\text { married } \\
\text { couples } \\
(\%)\end{array}$ & $\begin{array}{c}\text { All } \\
\text { men } \\
(\%)\end{array}$ & $\begin{array}{l}\text { Living } \\
\text { alone } \\
(\%)\end{array}$ & $\begin{array}{c}\text { Living as } \\
\text { married } \\
\text { couples } \\
(\%)\end{array}$ & $\begin{array}{c}\text { All } \\
\text { women } \\
(\%)\end{array}$ & $\begin{array}{c}\text { Living } \\
\text { alone } \\
(\%)\end{array}$ & $\begin{array}{c}\text { Living as } \\
\text { married } \\
\text { couples } \\
(\%)\end{array}$ & \\
\hline $\mathrm{Up}$ to 69 & 12 & 20 & 18 & 55 & $5^{8}$ & 57 & 43 & 40 & $4 I$ \\
\hline & 19 & 54 & 47 & 25 & 30 & 28 & 23 & & 36 \\
\hline \multirow[t]{2}{*}{75 and over } & 69 & 26 & 35 & 20 & 12 & 15 & 34 & 19 & 23 \\
\hline & \multicolumn{9}{|c|}{ No. of individuals } \\
\hline All ages $(100 \%)$ & 26 & 99 & 125 & 69 & 109 & I7 8 & 95 & 208 & 303 \\
\hline
\end{tabular}

Housing and gardens. The survey carried out by the Sheffeld Council of Social Service (Greenlees \& Adams, 1950) showed that $91 \%$ of the elderly in Sheffield lived in houses of the two-storey type. This was true of exactly the same proportion of the 
old people living alone and as married couples who completed the social and food survey. Many of the elderly had perhaps more room than they could make use of; well over half of all those living on their own had, for instance, four or more habitable rooms.* Of those living as married couples half had five or more rooms (Table 3 ). Often, particularly where there was sickness or disability, only the ground-floor rooms were in use.

Table 3. Number of habitable rooms in the homes of those surveyed

$\begin{array}{ccc}\begin{array}{c}\text { No. of rooms per head of those living alone } \\ \text { or per married couple }\end{array} & \begin{array}{c}\text { Living alone } \\ (\%)\end{array} & \begin{array}{c}\text { Living as } \\ \text { married couples } \\ (\%)\end{array} \\ \text { I } & 8 & - \\ 2 & 16 & 4 \\ 3 & 13 & 16 \\ 4 & 39 & 27 \\ 5 & 19 & 36 \\ 6 \text { and more } & 2 & 15 \\ \text { Not ascertained } & 3 & 2 \\ \text { Average no. of rooms per person } & 3.5 & 2.25 \\ \text { Total no. of individuals (100\%) } & 95 & 208\end{array}$

Table 4. Amount of rent including rates paid weekly by the elderly living alone or as married couples

\begin{tabular}{|c|c|c|c|}
\hline \multirow[b]{2}{*}{$\begin{array}{l}\text { Weekly rent including rates per head of } \\
\text { those living alone or per married couple }\end{array}$} & \multicolumn{3}{|c|}{ Proportion paying the rent of those } \\
\hline & $\begin{array}{c}\text { Living } \\
\text { alone } \\
(\%)\end{array}$ & $\begin{array}{c}\text { Living as } \\
\text { married } \\
\text { couples } \\
(\%)\end{array}$ & $\begin{array}{c}\text { In both } \\
\text { categories } \\
(\%)\end{array}$ \\
\hline $\mathrm{Up}$ to $5 s$ & 4 & $\mathbf{I}$ & 2 \\
\hline Over $5 s$. to Ios. & $6 I$ & 47 & 52 \\
\hline Over Ios. to I5s. & 28 & 37 & 34 \\
\hline Over I5s. to $20 s$. & 6 & II & 9 \\
\hline Over 20s. to $30 s$. & $\mathbf{I}$ & $\mathbf{3}$ & 2 \\
\hline Over 3 os, to $£_{2}$ & - & - & - \\
\hline Over $£_{2}$ & - & 一 & - \\
\hline Not ascertained & - & $\mathbf{I}$ & $\mathbf{I}$ \\
\hline Average rent per household & 9s. rod. & I Is. rod. & I1s. $2 d$. \\
\hline Total no. of individuals (100\%) & 83 & 150 & 233 \\
\hline
\end{tabular}

Of the subjects $22 \%$ owned or were buying their houses, $1 \%$ had accommodation rent-free, and the remainder paid rent. Payments on mortgage and rates or, for those who were fully paid up, rates only, ranged from $4 s$. $6 d$. to $£$ I. Ios. a week. The majority of those who rented their dwellings paid between $5^{s}$. and $15^{s}$. a week, including rates (Table 4). Although there were individual instances of high rents, particularly among those with one room only, those living in flats or rooms paid on an average a lower rent ( $7 s .9 d$.) than those who lived in rented dwellings (I Is. $2 d$. .).

* A habitable room was considered to be one which could be lived in, whether it was in use at the moment or not. Attics, storerooms, bathrooms and sculleries were not counted as habitable rooms. 
Also, the smaller the dwelling the lower the rent. People living in dwellings with two habitable rooms paid on an average $6 s$. Iod. a week, which rose to Ios. Id. for three rooms, IOs. $3 d$. for four, and $12 s .5 d$. for five rooms.

Since the majority of the old people lived in houses, a fairly large proportion of them $(57 \%)$ had gardens. Just over a quarter of those having gardens (i.e. 15\% of all the old people included in the social and food survey) used part of their gardens to grow food. Only $3 \%$ of the old people kept chickens.

Domestic arrangements and difficulties. $45 \%$ of those living alone and $33 \%$ of those living as married couples said they got help with their shopping or their housework. Nearly half of all the old people ( $44 \%$ ) who had help said they had it fairly regularly, either every day of the week for an hour or more, or two or three times a week, but about one-quarter of them ( $26 \%$ ) got help only very occasionally. In $52 \%$ of all cases the help came from relatives, and in $12 \%$ from friends or neighbours. Over a third $(36 \%)$ of the old people had paid domestic help, and a further $10 \%$ had a home help provided by the Local Authority. The percentages show that a few subjects had domestic help from more than one source.

Of those who got no help, just over one-tenth ( $13 \%$ ) said they could, in fact, do with some, and a small proportion of others $(6 \%)$ made it clear that, although they could manage themselves, it required some real effort. The remainder said definitely that they preferred to look after themselves.

Although only just over one-third normally had help with their household duties, over two-thirds $(73 \%)$ said they would be able to get help in the house in times of sickness or emergency, but a disturbingly high proportion, about $27 \%$ both of those living alone and those living as married couples, thought they would not be able to get help even in such circumstances. The explanation may partly be that $14 \%$ of all the subjects interviewed had no family or relatives in Sheffield and a further $46 \%$ had no family living nearby.

When asked whether they had any particular difficulties in getting food, less than I \% mentioned physical difficulties such as queueing. The remainder who mentioned some difficulty spoke of the shortage of rations, the lack of variety or the high prices; as high a proportion, however, as $63 \%$ said they had no particular difficulty in getting food.

All the old people interviewed had cooking facilities of some kind, although $69 \%$ had to rely entirely on the old-fashioned oven range. A further $7 \%$ had a gas ring as well as the range; $\mathrm{I} \%$ had only a gas ring or electric plate. The remainder had an electric or a gas cooker.

Employment. Thirty-eight, or $\mathrm{I}_{3} \%$ of the subjects interviewed were still in employment; seventeen of them were women. Fifteen of the seventeen were under the age of 69 ; the remaining two were between 70 and 74 . Five of the twenty-one men still at work were under 70 ; ten were between 70 and 74 and six were over 74 . The proportion of those living alone $(14 \%)$ who were still at work was approximately the same as of those living as married couples $(12 \%)$. The numbers of the thirty-eight subjects following occupations arranged in broad categories based on the Registrar General's classification were professional and intermediate seven, skilled twenty-one, 
partly skilled and unskilled ten. The women were employed almost entirely in retail trade or as domestic servants. Income from earnings ranged from $\oint_{0} \mathrm{r}$ a week for one man who was a part-time steel dresser to $£ 7$ a week for a Methodist minister. In seven of the thirty-eight cases mentioned above both of the old people in the household were in employment. In thirty-five additional cases the husband or wife of the subject was in employment, so that current earnings formed part or all of the income of seventy-three $(24 \%)$ of the old people completing the survey. Since only $14 \%$ of those living alone were at work, only this proportion had income from earnings, compared with $29 \%$ of those living as married couples.

\section{Income and expenditure}

Sources of income. The income of the majority of those interviewed consisted entirely of the old-age pension, supplemented for some of them by national assistance. Only small proportions derived their income entirely from current earnings or from savings and other private sources. Just because they were on the whole older, more of those living alone than of those living as married couples had no other source of income than their pension (Table 5).

Table 5. Sources of income of the elderly people surveyed

\begin{tabular}{|c|c|c|c|}
\hline & \multicolumn{3}{|c|}{ Proportions drawing the income of those } \\
\hline Source of income & $\begin{array}{c}\text { Living } \\
\text { alone } \\
(\%)\end{array}$ & $\begin{array}{c}\text { Living as } \\
\text { married } \\
\text { couples } \\
(\%)\end{array}$ & $\begin{array}{c}\text { In both } \\
\text { categories } \\
(\%)\end{array}$ \\
\hline $\begin{array}{l}\text { bject or spouse, from any source, } \\
\text { lational assistance }\end{array}$ & 60 & 39 & 46 \\
\hline $\begin{array}{l}\text { or spouse together with income } \\
\text { ces or savings }\end{array}$ & 18 & 20 & Ig \\
\hline et or spouse and income from & 13 & $2 \mathbf{I}$ & I8 \\
\hline nly & - & 8 & 6 \\
\hline ate sources or savings only & $\begin{array}{l}6 \\
3\end{array}$ & $\begin{array}{l}3 \\
9\end{array}$ & $\begin{array}{l}4 \\
7\end{array}$ \\
\hline duals $(100 \%)$ & 95 & 208 & $3 \circ 3$ \\
\hline
\end{tabular}

Size of income. The average total weekly income per head from all sources was 39s. $7 d$. Those living alone had an average of 4 Is. $8 d$., compared with $39 s$. for those living as married couples. The frequency of the different sizes of incomes is shown in Table 6. Of all the elderly living alone, $43 \%$ had a total household income of less than $35^{5}$. per head compared with $54 \%$ of those living as married couples. On the other hand more of those living as married couples than of those living alone had an income of over 5 os./head/week. The probable explanation is that more of them had sources of income other than the old-age pension.

Expenditure. The subjects were asked to record each day's purchases and any gifts of food they received during the week or any produce they used from their garden. Expenditure on sweets was included also. Information about other items was 
collected by the field worker during or at the end of the survey week. If the subject was not able to say what the week's expenditure on lighting and fuel had been, an average for the week was arrived at by examining the bills for heating at the period of the year, whether summer or winter, in which the survey was being made. Usually there was no difficulty over expenditure on coal since the subjects purchased it in bags weekly or monthly.

Table 6. Total household income per head of the elderly people surveyed

\begin{tabular}{|c|c|c|c|}
\hline \multirow[b]{2}{*}{ Income per head } & \multicolumn{3}{|c|}{ Proportion drawing the income of those } \\
\hline & $\begin{array}{l}\text { Living } \\
\text { alone } \\
(\%)\end{array}$ & $\begin{array}{c}\text { Living as } \\
\text { married } \\
\text { couples } \\
(\%)\end{array}$ & $\begin{array}{c}\text { In both } \\
\text { categories } \\
(\%)\end{array}$ \\
\hline Up to $3 \circ$ s. & 12 & 42 & 32 \\
\hline Over 3 os. to $35 s$ & $3 \mathbf{I}$ & 12 & 18 \\
\hline Over $35 \mathrm{~s}$. to $50 \mathrm{~s}$. & 37 & 16 & 23 \\
\hline Over 5os. & I6 & 26 & 23 \\
\hline Not ascertained & 4 & 4 & 4 \\
\hline Total no. of individuals ( $100 \%$ ) & 95 & 208 & 303 \\
\hline
\end{tabular}

Table 7 shows the average weekly expenditure on the different items for each income group of those living alone and as married couples. The expenditure per head on food was greater in the two higher income groups than in the two lower ones. Expenditure on rent increased with income, but expenditure on fuel varied little with difference in income. Personal taste must have influenced the expenditure on drink and tobacco to a considerable extent, which probably accounts for the small variation with income in the three lowest income groups; with incomes of over 5os./head/week, however, markedly greater sums were spent on tobacco and drink. The expenditure on the different items by those who would not answer the questions about total income, showed that they had higher rather than lower incomes.

On the whole, those living as married couples had more left over from their incomes to spend on items not included in the survey, than those with the same income but living alone. In fact, those with small incomes who were living alone had little or no margin to spare.

Produce from gardens and gifts of food. Fifteen (16\%) of those living alone and twenty-two ( $\mathrm{I} \mathrm{I} \%$ ) of those living as married couples received gifts of food from relatives or friends during the survey week. Included among them are the three or four who said they had eaten produce from their own gardens. The gifts varied from cake and fruit to five or six free midday meals cooked by a relative. The gifts and garden produce were valued at current prices and their value ranged from $4 d$. for a gift of rhubarb to I $2 s$. for free meals. The total value of gifts received by old people living as married couples was $39 s$. Io $d$., and for those living alone $43 s .4 d$. These amounts are equivalent to $1 d$./head/week for those living as married couples and $5 d$. for those living alone. 


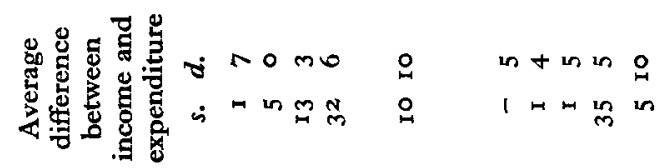

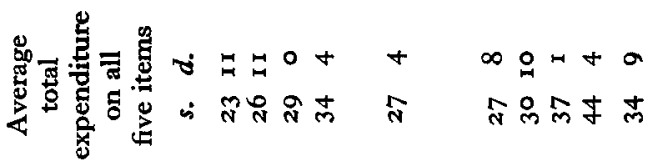

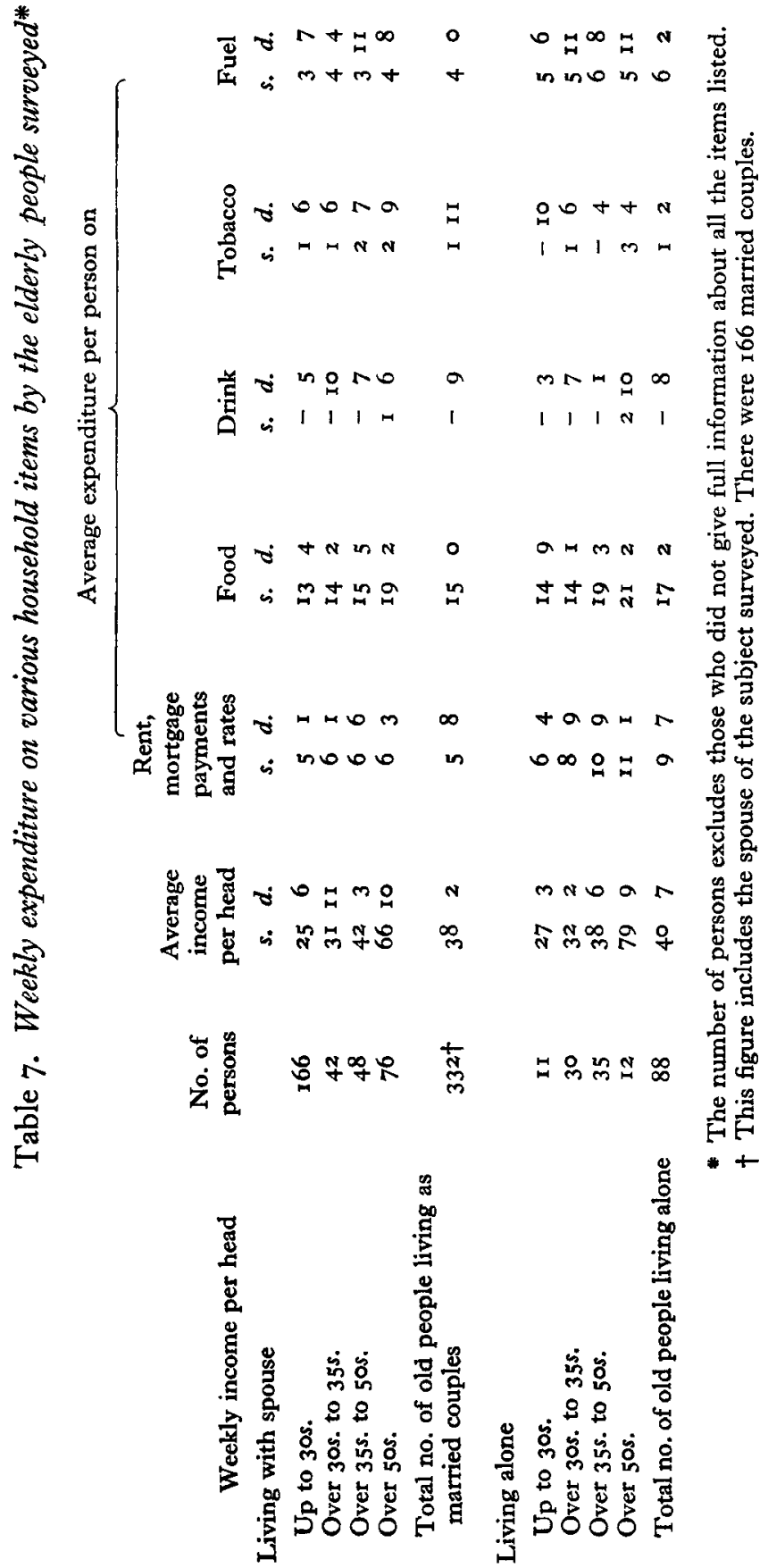




\section{Food consumption and factors affecting it}

Sex and age. Table 8 shows the average weekly consumption of different foods by men and women of different ages. The men ate more than the women of bread, breakfast cereals, potatoes, root vegetables, cheese, meat, bacon, soups and gravies,

Table 8. Average weekly amounts per head of foods analysed according to sex and age eaten by the elderly people surveyed

\begin{tabular}{|c|c|c|c|c|c|c|c|c|c|}
\hline \multirow[b]{3}{*}{ Food item } & \multirow[b]{3}{*}{ Unit } & \multicolumn{8}{|c|}{ Average weekly consumption of food per head by } \\
\hline & & \multicolumn{4}{|c|}{ Men (age) } & \multicolumn{4}{|c|}{ Women (age) } \\
\hline & & $\begin{array}{c}\text { Up to } \\
69\end{array}$ & $\begin{array}{c}70 \text { to } \\
74\end{array}$ & $\begin{array}{l}75 \text { and } \\
\text { over }\end{array}$ & $\begin{array}{c}\text { All } \\
\text { ages }\end{array}$ & $\begin{array}{l}\text { Up to } \\
69\end{array}$ & $\begin{array}{c}70 \text { to } \\
74\end{array}$ & $\begin{array}{l}75 \text { and } \\
\text { over }\end{array}$ & $\begin{array}{c}\text { All } \\
\text { ages }\end{array}$ \\
\hline Bread & oz. & $58 \cdot 8$ & $54 \cdot 6$ & $54^{\circ} \circ$ & $55 \cdot 2$ & $40 \cdot 9$ & $39 * 3$ & $36 \cdot 5$ & $39 \cdot 7$ \\
\hline Breakfast cereals & oz. & 10.4 & $6 \cdot 8$ & $5 \cdot 5$ & $7 \cdot 0$ & $2 \cdot 6$ & 3.0 & $3 \cdot 6$ & $2 \cdot 9$ \\
\hline Cakes, biscuits & oz. & $10 \cdot 7$ & $14 \cdot 3$ & $11 \cdot 2$ & 12.5 & 14.7 & $12 \cdot 0$ & $10 \cdot 3$ & $13 \cdot 3$ \\
\hline Milk, cream & pint & $3 \cdot 2$ & $3 \cdot I$ & $3 \cdot 0$ & $3 \cdot I$ & $3 \cdot 2$ & 3.4 & $3 \cdot 3$ & $3 \cdot 3$ \\
\hline Cheese & oz. & $2 \cdot 5$ & $2 \cdot 9$ & $2 \cdot 6$ & $2 \cdot 7$ & $I \cdot 9$ & $I \cdot 5$ & $I \cdot 4$ & $I \cdot 7$ \\
\hline Cheese dishes & oz. & 0.3 & 0.4 & 0.3 & 0.3 & 0.2 & 0.4 & 0.4 & 0.3 \\
\hline Eggs & no. & $2 \cdot 3$ & $2 \cdot 7$ & $3 \cdot I$ & $2 \cdot 8$ & $2 \cdot 5$ & $2 \cdot 2$ & $x \cdot 7$ & $2 \cdot 3$ \\
\hline Fish & oz. & $6 \cdot 8$ & $5 \cdot 8$ & $4^{\circ} 0$ & $5 * 4$ & $5 \cdot 6$ & 5.5 & $4 \cdot 2$ & $5 \cdot 4$ \\
\hline Meat, bacon, sausage & oz. & $21 \cdot 7$ & $23 \cdot 1$ & $23 \cdot 8$ & $23 \cdot 1$ & $14 \cdot 8$ & I4. I & $16 \cdot 1$ & 14.8 \\
\hline Fats & oz. & $8 \cdot 3$ & $7 \cdot 0$ & 7.9 & $7 \cdot 5$ & $7 \cdot 6$ & $7 \cdot 2$ & $6 \cdot 9$ & $7 \cdot 4$ \\
\hline Fruit, nuts & oz. & $7 \cdot 8$ & 10.9 & $8 \cdot 2$ & $9 \cdot 4$ & $12 \cdot 4$ & $14 \cdot 6$ & $10 \cdot 2$ & $12 \cdot 7$ \\
\hline Potatoes, chips & oz. & $28 \cdot 2$ & $25 \cdot 2$ & $20 \cdot 3$ & $24 \cdot 1$ & I 7.9 & $18 \cdot 5$ & $15 \cdot 7$ & $17 \cdot 7$ \\
\hline Vegetables, green & oz. & $7 \cdot 3$ & $4: 7$ & 3.5 & $4^{\cdot 8}$ & $4^{\circ} 0$ & $4 \cdot 9$ & $3 \cdot 1$ & $4^{*} \cdot 1$ \\
\hline Vegetables, other & oz. & $6 \cdot 6$ & 6.0 & $6 \cdot 1$ & $6 \cdot 1$ & $5 \cdot 2$ & $4 \cdot 0$ & $5 \cdot 6$ & $4^{\circ} 9$ \\
\hline Sugar & oz. & $6 \cdot 0$ & $7 \cdot 3$ & $5 \cdot 7$ & $6 \cdot 5$ & $5 \cdot 9$ & $5 \cdot 4$ & $5 \cdot 9$ & $5 \cdot 7$ \\
\hline Preserves & oz. & $5 \cdot 3$ & $5 \cdot 8$ & 6.3 & $5 \cdot 9$ & $4 \cdot 6$ & 4.3 & $3 \cdot 4$ & $4 \cdot 3$ \\
\hline Sweets, ice-cream & oz. & 0.8 & 0.7 & 0.8 & 0.7 & $1 \cdot 0$ & $1 \cdot 0$ & 0.5 & 0.9 \\
\hline Puddings and sauces & oz. & $20 \cdot 8$ & $25 \cdot 2$ & $17 \cdot 6$ & $21 \cdot 7$ & $19 \cdot 3$ & $2 I \cdot 0$ & $13 \cdot 5$ & $18 \cdot 9$ \\
\hline Stew, meat pudding & oz. & $3 \cdot 8$ & $2 \cdot 6$ & $\mathrm{I} \cdot 6$ & $2 \cdot 5$ & $3 \cdot 2$ & $\mathbf{I} \cdot \mathbf{I}$ & $\mathbf{I} \cdot 3$ & $2 \cdot 3$ \\
\hline Soup, gravy & oz. & $18 \cdot 1$ & $17: 7$ & 19.7 & $18 \cdot 5$ & $12 \cdot 9$ & $11 \cdot 9$ & I $1 \mathbf{3}$ & 12.4 \\
\hline Others & oz. & $0 \cdot 1$ & 0.3 & 0.5 & 0.3 & 0.3 & 0.4 & 0.4 & 0.3 \\
\hline \multicolumn{2}{|c|}{ No. of individuals in group } & 23 & $5^{8}$ & 44 & 125 & IOI & 50 & 27 & I 78 \\
\hline
\end{tabular}

sugar and preserves. The women, on the other hand, ate more fruit. There were differences also with age among both men and women, although generally they were less pronounced than between the sexes. The older the men the less they ate of bread, breakfast cereals, potatoes, green vegetables, and meat puddings and stews. The women, as they grew older, ate less bread, cakes and biscuits, fish, eggs, puddings and stews. For all foods there were wide variations in the amounts eaten by individuals; for example the milk drunk ranged from almost nothing to I2 pints a week for men and over $8 \frac{1}{2}$ pints for women. The average consumption of milk, including that in made-up dishes, was between 3 and 4 pints a week for both men and women.

Life alone or as married couples. Generally both men and women who were living alone ate less than those living as married couples of the foods that require some preparation. For example, men and women living as married couples ate $25^{\cdot} \mathrm{I}$ and 19.2 oz., respectively, of potatoes during the survey week, compared with 20.0 and $15.4 \mathrm{oz}$., respectively, for men and women living alone. Living as married couples, men ate also $23 \cdot 6 \mathrm{oz}$. of puddings and sauces and women ate $22 \cdot \mathrm{I} \mathrm{oz}$., compared with 
I $4.5 \mathrm{oz}$. for men living alone and $13.9 \mathrm{oz}$. for women living alone. Men living alone ate less fish, but more meat and bacon. They ate rather more bread than men living as married couples, even though they were older and would, therefore, be expected to eat less. Cakes, biscuits and fruit were taken in greater quantities by men living as married couples than by men living alone. Clearly the food pattern of the married men would be to some extent influenced by the tastes of their wives.

Health. There were differences in the amounts of different foods eaten by men and women who were classified as fit, moderately fit, or unfit, although, taken as a whole, the differences were not substantial. Men who were fit ate more breakfast cereals, fruit, green vegetables and puddings than the moderately fit or unfit. The consumption of meat and bacon tended to fall when a worsening of the state of health occurred. Women ate less cakes and biscuits, fish, green vegetables and preserves when their health deteriorated. The consumption of potatoes by those who were unfit was somewhat less than by the others. The amount of soup drunk increased when there was a worsening of the state of health, but the amount of milk consumed varied little according to the state of health.

Social group. The social grouping was based on the main occupation followed during the subject's lifetime, even though at the time of the inquiry the occupation might have changed. For all married women the occupation was classified according to the husband's main occupation. For the purpose of the analysis the Registrar General's five social groups were reduced to three. They were: I and II professional and intermediate, III skilled, IV and V partly skilled and unskilled.

As Table 9 shows, greater quantities of the more palatable foods like cakes and biscuits, milk, vegetables other than green, fruit, puddings and sauces, and sweets, were eaten in the higher social groups by both men and women. The reverse was true of bread, green vegetables, and stews. Men in the highest social group also ate more breakfast cereals, fish and preserves, but slightly less potatoes. Women in the highest social group ate more meat. Because they ate more bread, the lower social groups tended to eat more of the fats that are spread on bread.

Income. When divided into groups according to their actual income per head, men and women with over 35 s./head/week had rather more milk, cakes and biscuits, root and other vegetables, sweets and fruit than those with less than 35s. With higher incomes, men ate more breakfast cereals, cheese, meat, sugar and bacon, puddings, stews and soup, whereas women had somewhat more eggs and fish but less preserves and bread.

Those of the elderly whose only source of income was the old-age pension with or without national assistance ate less of a large number of foods than those who had other sources of income (Table Io). The difference between the two groups was particularly marked with men, who ate less of sixteen of the twenty-one food items if they had only the old-age pension with or without national assistance. Women in the same position ate more bread but less cake and biscuits, fruit and puddings, and slightly less fish and potatoes. An analysis by age and source of income shows that in spite of the fact that the pensioners were older as a group, the operative factor in most instances in the amounts of different foods taken was the size of their income and not their age. 
Table 9. Average weekly amounts per head of foods, eaten by the elderly people surveyed, analysed according to social class (Great Britain, Registrar General, 1951)*

Average weekly consumption of food per head by

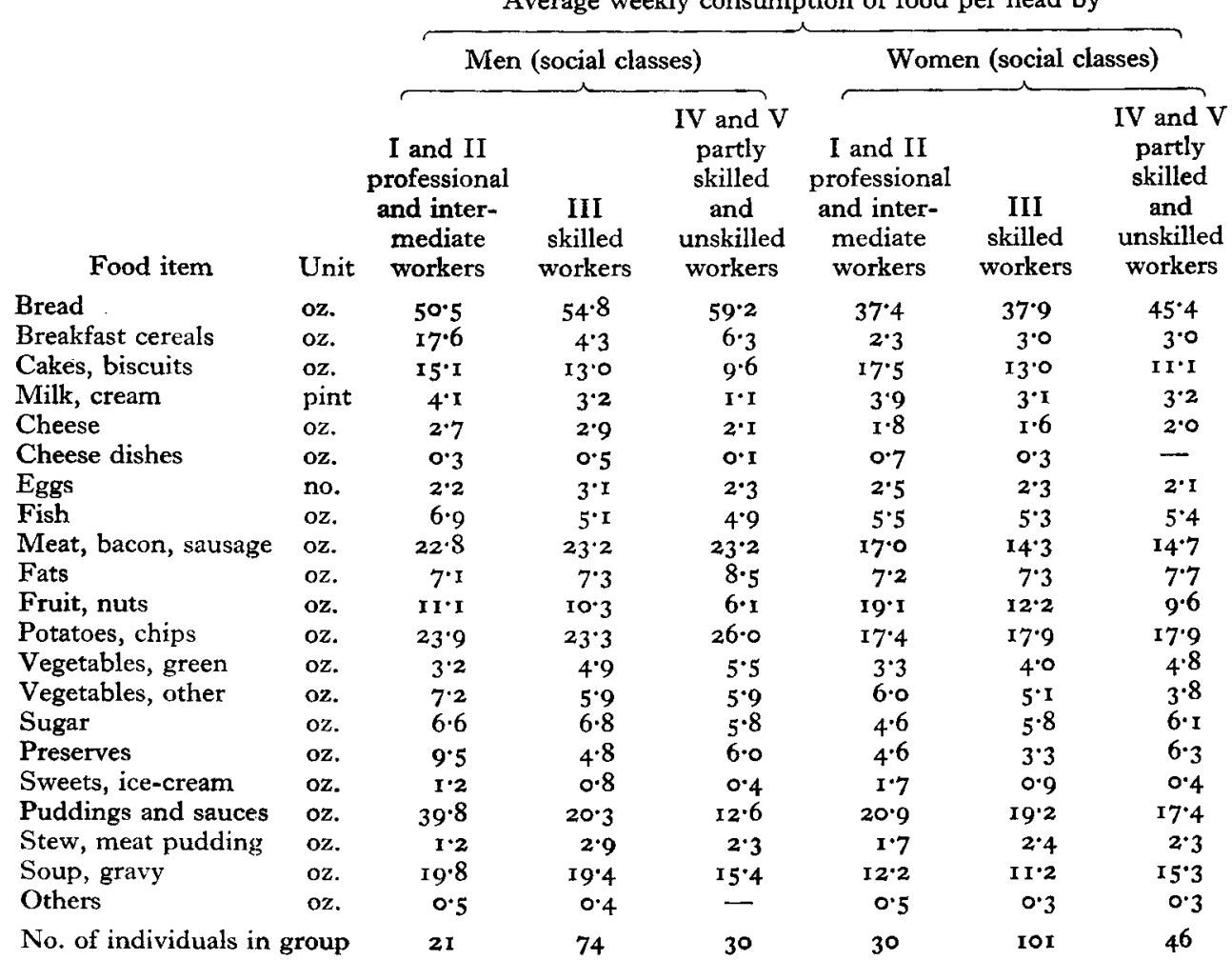

* Married women were included in the social class of the husband.

\section{Intake of calories and nutrients and factors affecting it}

Age and sex. Table I I shows the average daily intake of calories and nutrients of men and women of different ages. The women's intake of calories, animal and vegetable protein, fat, carbohydrate, iron, vitamin $\mathrm{A}$ and the $\mathrm{B}$ vitamins was lower than the men's. Men of 75 and over had less calories than men below 75, and there was a falling off with age in the intake of vitamin C. Women, as they grew older, had less calories, fat, iron and vitamins, except vitamin $\mathrm{C}$.

Table 12 shows the frequency distribution of the intakes of calories and nutrients. There were many subjects whose intakes were well below the standards suggested by various expert bodies.

Life alone or as married couples. Men living as married couples had an average daily intake of 2109 Cal. compared with 2048 for men living alone, the corresponding figures for women being $179 \mathrm{I}$ and 1675 . An analysis by age, however, shows that men over 70 who were living alone had a higher intake of calories than men of the same age living as married couples, doubtless because they had more foods, like bread and shop-made meat pies, that required no home preparation. Men living as 
Table 10. Average weekly amounts per head of foods eaten by the elderly people surveyed, analysed according to whether there was any source of income other than an old-age pension*

Average weekly consumption of food per head by

\begin{tabular}{|c|c|c|c|}
\hline \multicolumn{2}{|c|}{ Men having } & \multicolumn{2}{|c|}{ Women having } \\
\hline $\begin{array}{l}\text { An old-age } \\
\text { pension only } \\
\text { with or } \\
\text { without } \\
\text { national } \\
\text { assistance }\end{array}$ & $\begin{array}{l}\text { Other sources } \\
\text { of income } \\
\text { with or } \\
\text { without } \\
\text { an old-age } \\
\text { pension }\end{array}$ & $\begin{array}{c}\text { An old-age } \\
\text { pension only } \\
\text { with or } \\
\text { without } \\
\text { national } \\
\text { assistance }\end{array}$ & $\begin{array}{l}\text { Other sources } \\
\text { of income } \\
\text { with or } \\
\text { without } \\
\text { an old-age } \\
\text { pension }\end{array}$ \\
\hline $\begin{array}{r}54^{\circ} 9 \\
5.7\end{array}$ & $\begin{array}{r}55 \cdot 3 \\
7 \cdot 6\end{array}$ & $\begin{array}{r}42 \cdot 0 \\
3 \cdot 5\end{array}$ & $\begin{array}{r}38 \cdot 6 \\
2 \cdot 6\end{array}$ \\
\hline $10 \cdot 1$ & 13.7 & 10.9 & $14 \cdot 5$ \\
\hline $2 \cdot 8$ & $3 \cdot 2$ & $3 \cdot 2$ & $3 \cdot 3$ \\
\hline $2 \cdot 2$ & $3 \cdot 0$ & $x \cdot 7$ & $1 \cdot 7$ \\
\hline 0.2 & 0.4 & 0.2 & 0.3 \\
\hline $2 \cdot 8$ & $2 \cdot 8$ & $2 \cdot 0$ & $2 \cdot 4$ \\
\hline $5 \cdot 8$ & $5 \cdot 2$ & $4 \cdot 5$ & $5 \cdot 8$ \\
\hline $22 \cdot 2$ & $23 \cdot 6$ & $14 \cdot 6$ & 14.9 \\
\hline $7 \cdot 8$ & $7 \cdot 4$ & $7 \cdot 3$ & $7 \cdot 5$ \\
\hline $8 \cdot 3$ & $9 \cdot 9$ & 9.0 & 14.6 \\
\hline 20.2 & $25 \cdot 9$ & $16 \cdot 2$ & $18 \cdot 5$ \\
\hline $3 \cdot 8$ & $5 \cdot 2$ & $4 \cdot 6$ & 3.9 \\
\hline 4.5 & $6 \cdot 9$ & $4 \cdot 8$ & $5^{\circ} 0$ \\
\hline $6 \cdot 0$ & $6 \cdot 7$ & $5^{\cdot 8}$ & $5 \cdot 7$ \\
\hline $5 \cdot 3$ & $6 \cdot 2$ & $5 \cdot 0$ & $4 \cdot 0$ \\
\hline 0.8 & 0.7 & 0.5 & $I \cdot I$ \\
\hline $12 \cdot 5$ & $26 \cdot 0$ & 14.0 & $21 \cdot 5$ \\
\hline 0.9 & 3.2 & $2 \cdot 3$ & $2 \cdot 2$ \\
\hline $2 x \cdot 7$ & $17^{\circ} 0$ & $12 \cdot 4$ & $12 \cdot 4$ \\
\hline $0 \cdot I$ & 0.4 & 0.3 & 0.4 \\
\hline 40 & 85 & $6 I$ & 117 \\
\hline
\end{tabular}

Bread
Breakfast cereals
Cakes, biscuits
Milk, cream
Cheese
Cheese dishes
Eggs
Fish
Meat, bacon, sausage
Fats
Fruit, nuts
Potatoes, chips
Vegetables, green
Vegetables, other
Sugar
Preserves
Sweets, ice-cream
Puddings and sauces
Stew, meat pudding
Soup, gravy
Others

No. of individuals in group

* A pension from previous employment is counted as income from another source.

Table I r. Average daily intake of calories and nutrients by the elderly people surveyed, analysed according to age

\begin{tabular}{|c|c|c|c|c|c|c|c|c|c|}
\hline \multirow[b]{3}{*}{ Nutrient } & \multirow[b]{3}{*}{ Unit } & \multicolumn{8}{|c|}{ Average daily intake of calories and nutrients per head by } \\
\hline & & \multicolumn{4}{|c|}{ Men (age) } & \multicolumn{4}{|c|}{ Women (age) } \\
\hline & & $\begin{array}{c}\text { Up to } \\
69\end{array}$ & $\begin{array}{c}70 \text { to } \\
74\end{array}$ & $\begin{array}{l}75 \text { and } \\
\text { over }\end{array}$ & $\begin{array}{c}\text { All } \\
\text { ages }\end{array}$ & $\begin{array}{c}\text { Up to } \\
69\end{array}$ & $\begin{array}{c}70 \text { to } \\
74\end{array}$ & $\begin{array}{c}75 \text { and } \\
\text { over }\end{array}$ & $\begin{array}{c}\text { All } \\
\text { ages }\end{array}$ \\
\hline Calories & Cal. & 2126 & 2154 & 2006 & 2096 & 1811 & 1700 & I 588 & I746 \\
\hline Vegetable protein & g. & 34 & 33 & 30 & 32 & 26 & 24 & 23 & 25 \\
\hline Animal protein & g. & 39 & 40 & 39 & 39 & 32 & 33 & $3 I$ & 32 \\
\hline Fat & g. & 85 & 86 & 84 & 85 & 77 & 73 & 68 & 74 \\
\hline Carbohydrate & g. & 268 & 273 & 245 & 262 & 222 & 207 & 191 & 213 \\
\hline Calcium & g. & 0.9 & 0.9 & 0.8 & 0.9 & 0.8 & 0.8 & 0.7 & 0.8 \\
\hline Iron & mg. & $I_{4}$ & 14 & I3 & $\mathrm{I}_{4}$ & I I & 10 & 9 & IO \\
\hline Vitamin A & i.u. & 2384 & 2314 & $235 I$ & 2340 & $2 \times 83$ & 2146 & 1802 & 2115 \\
\hline Thiamine & mg. & $I \cdot 2$ & $I \cdot I$ & $I \cdot I$ & $\mathbf{I} \cdot \mathbf{I}$ & 0.9 & 0.9 & 0.8 & 0.9 \\
\hline Riboflavin & mg. & $I \cdot 2$ & $I \cdot 2$ & $x \cdot I$ & $I \cdot x$ & $r \cdot 0$ & $I \cdot O$ & 0.9 & $I \cdot 0$ \\
\hline Nicotinic acid & mg. & 9 & 9 & 8 & 9 & 7 & 7 & 6 & 7 \\
\hline Vitamin C & mg. & 25 & 21 & 18 & $2 \mathbf{I}$ & 21 & 22 & 23 & 21 \\
\hline \multicolumn{2}{|c|}{ No. of individuals in group } & 23 & $5^{8}$ & 44 & 125 & IOI & 50 & 27 & 178 \\
\hline
\end{tabular}




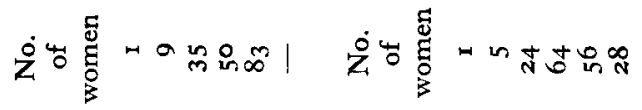

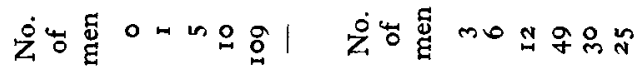

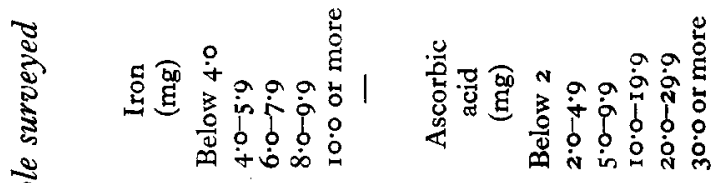

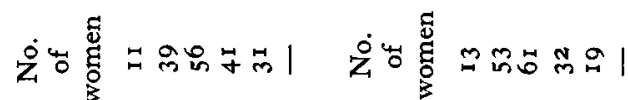

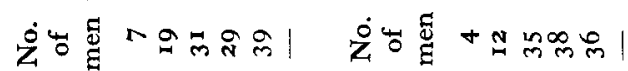

on

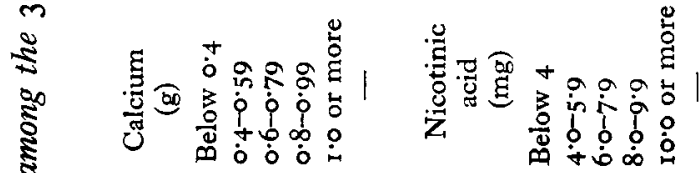

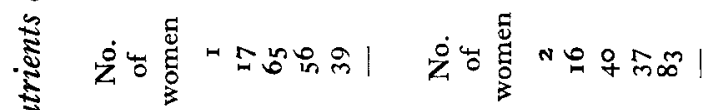

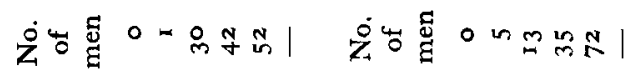

$\frac{0}{8}$

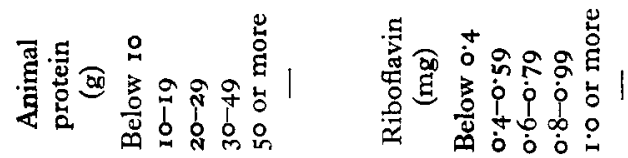

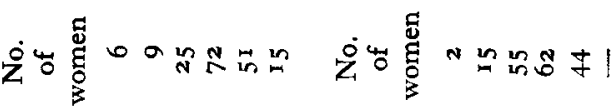

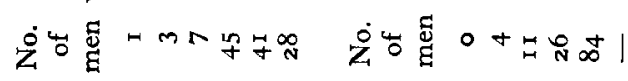

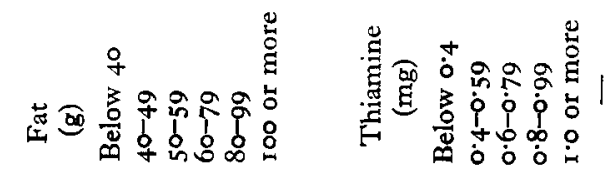

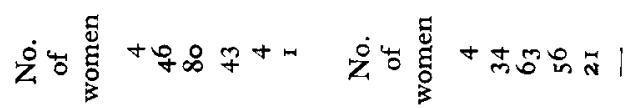

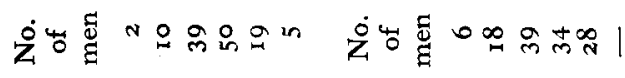

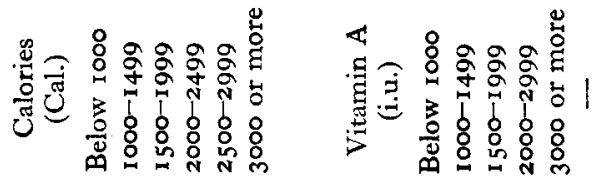


married couples, whatever their age, had more vitamin $\mathrm{C}$ and somewhat less vitamin $\mathrm{A}$ than those living alone. Women living as married couples had more vitamin A, protein and fats than those living alone.

Health. Table $\mathrm{I} 3$ shows the intake of calories and nutrients of certain of the elderly of different ages who on medical examination were graded as fit.

Table 13. Average daily intake per head of calories and nutrients of seventy-seven of the elderly subjects who were medically graded as fit

\begin{tabular}{|c|c|c|c|c|c|c|c|}
\hline \multirow[b]{3}{*}{ Nutrient } & \multirow[b]{3}{*}{ Unit } & \multicolumn{6}{|c|}{ Average daily intake per head of calories and nutrients by } \\
\hline & & \multicolumn{3}{|c|}{ Men (age) } & \multicolumn{3}{|c|}{ Women (age) } \\
\hline & & Up to 69 & 70 to 74 & 75 and over & Up to 69 & 70 to 74 & 75 and over \\
\hline Calories & Cal. & 2261 & 2254 & 2015 & 1902 & 1483 & 1740 \\
\hline Vegetable protein & $\mathrm{g}$ & 36 & 34 & 31 & 27 & 20 & 24 \\
\hline Animal protein & g & 38 & 43 & 32 & 35 & 25 & 36 \\
\hline Fat & g & $9 \mathbf{I}$ & 92 & 88 & 83 & 65 & 73 \\
\hline Carbohydrate & g & 287 & 279 & 244 & 230 & 181 & 213 \\
\hline Calcium & $\mathrm{g}$ & 0.9 & 0.9 & 0.7 & 0.8 & 0.6 & 0.7 \\
\hline Iron & $\mathrm{mg}$ & 16 & I 5 & 13 & I I & 8 & 10 \\
\hline Vitamin A & i.u. & 2356 & 2647 & 2094 & $243^{\circ}$ & 1872 & 1776 \\
\hline Thiamine & $\mathrm{mg}$ & $1 \cdot 3$ & $I \cdot I$ & I.O & 0.9 & 0.7 & 0.8 \\
\hline Riboflavin & mg & $1 \cdot 2$ & $I \cdot 2$ & 0.9 & $1 \cdot 1$ & 0.8 & 0.9 \\
\hline Nicotinic acid & mg & I I & 10 & 9 & 7 & 6 & 6 \\
\hline Vitamin $\mathrm{C}$ & $\mathrm{mg}$ & 32 & 23 & 19 & 23 & 16 & 17 \\
\hline \multicolumn{2}{|c|}{ No. of individuals in group } & 9 & 17 & 7 & 33 & 6 & 5 \\
\hline
\end{tabular}

Social group. Among both men and women, professional, managerial and executive workers had greater intakes of calories, proteins, fat, and vitamin A than skilled and unskilled workers. The men in the highest social class had greater intakes than those in the lower social classes also of carbohydrate, calcium, iron, thiamine and riboflavin (Table 14).

Income. Table 15 shows that at least for men, and to a less degree for women, intake of calories and almost all nutrients was greater the larger the income from sources other than the old-age pension and national assistance, whatever the age group. Table $\mathrm{I} 6$ compares the intake for those having nothing but the old-age pension with or without national assistance and for those having other sources of income with or without the old-age pension.

\section{The kinds of meal eaten}

Each meal of the day was classified into one of eight different types:

(I) A milk drink either alone or with bread.

(2) Cake either alone or with (I).

(3) A cooked protein meal, which may or may not include vegetables.

(4) (3) together with pudding, cake or bread.

(5) Cereals either alone or with (I) or (2).

(6) Cereals and a cooked protein dish, alone or with (I) or (2).

(7) Other meals, including salads, puddings or chips alone.

(8) No meal. A cup of tea only is counted as no meal. 
Table 14. Average daily intake of calories and nutrients by the elderly people surveyed, analysed according to social class (Registrar General's classification)

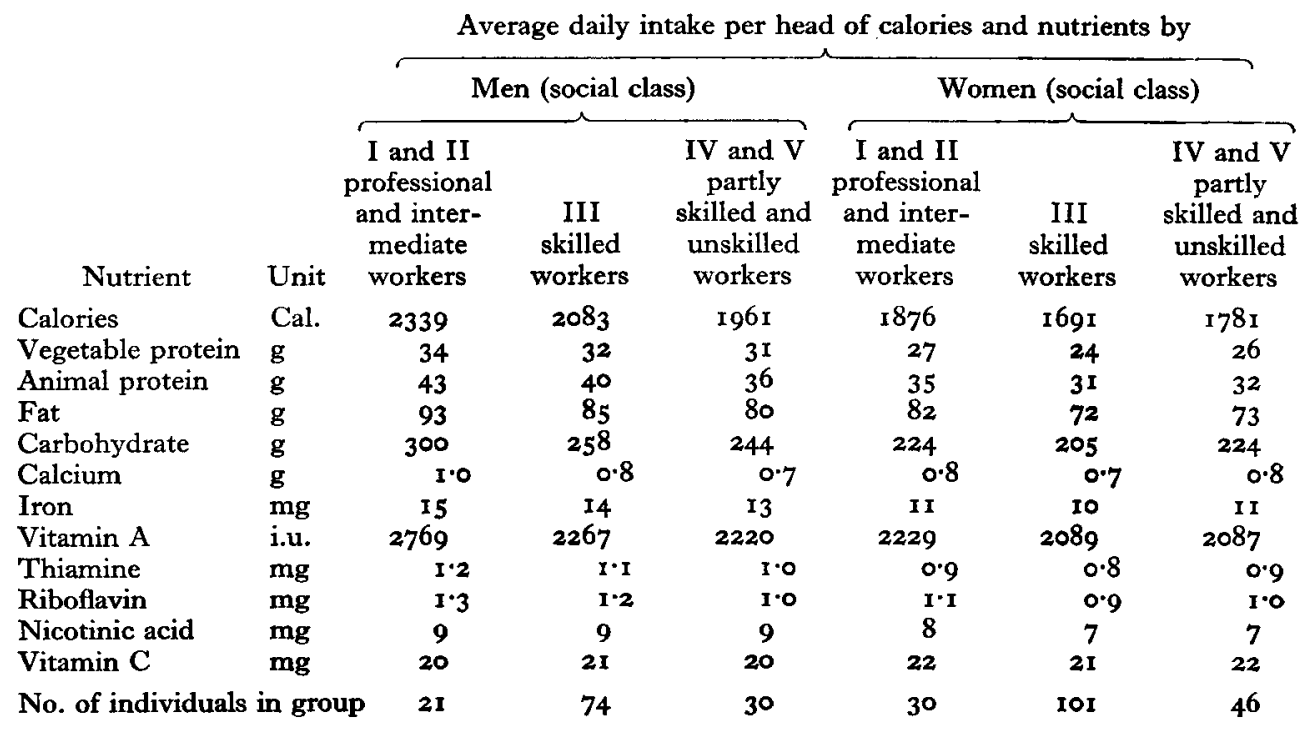

Table 1 5. Average daily intake of calories and nutrients by the elderly people surveyed, analysed according to average weekly income per head*

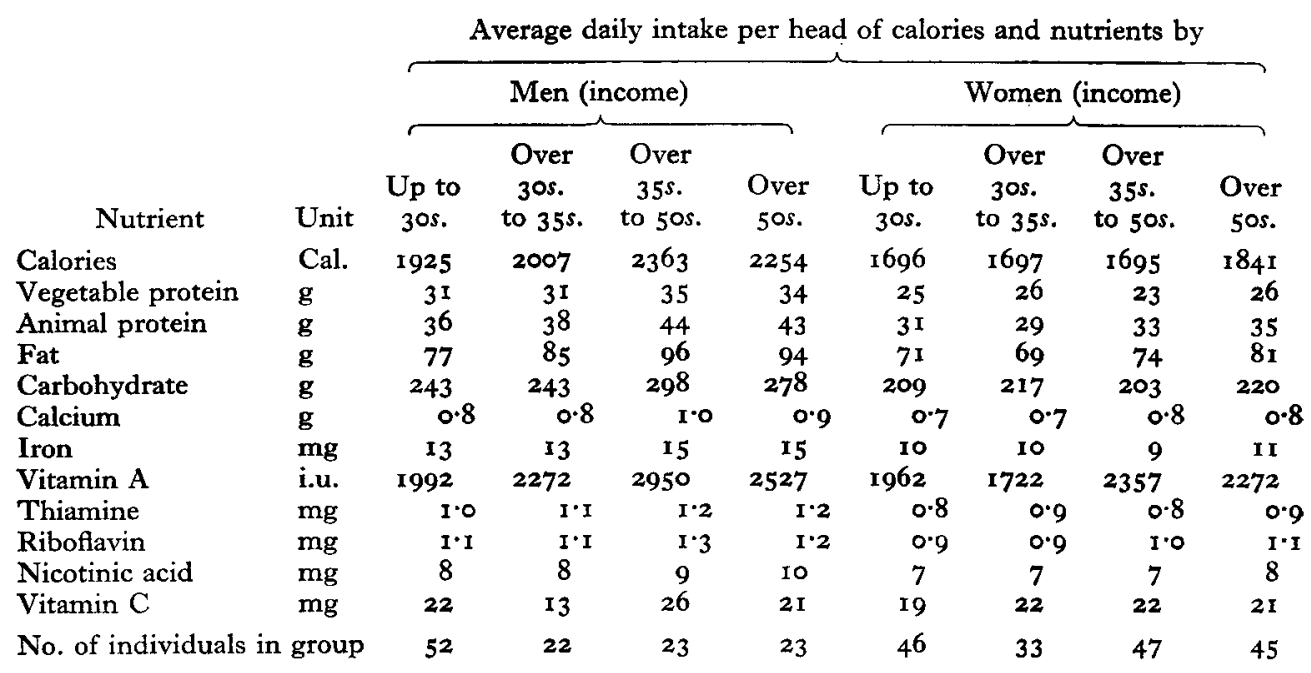

* Those are excluded whose exact total income was undeclared.

Table 17 shows the types of meal eaten at different times of the day by men and women; there were some differences with age but they were not great so the data for the various age groups have been combined.

Of all the meals eaten by the women during the survey week, the proportion that was of the bread, biscuit and cake type with or without a drink of some kind was $45 \%$, compared with $33 \%$ for the men. Of the meals eaten by the men, on the other 
hand, $55 \%$ contained some cooked protein, compared with $45 \%$ of those eaten by the women.

Variation of eating habits with age was shown in certain particulars. The proportion of meals containing cooked protein accounted for $34 \%$ of the teas and suppers eaten by women of up to 69 years of age but for only $23 \%$ of those eaten by women of 75 and over. At the same time rather more teas and suppers of the bread and cake variety were eaten by the older women, who also more often omitted tea and supper altogether.

Table 16. Average daily intake of calories and nutrients by the elderly people surveyed, analysed according to source of income

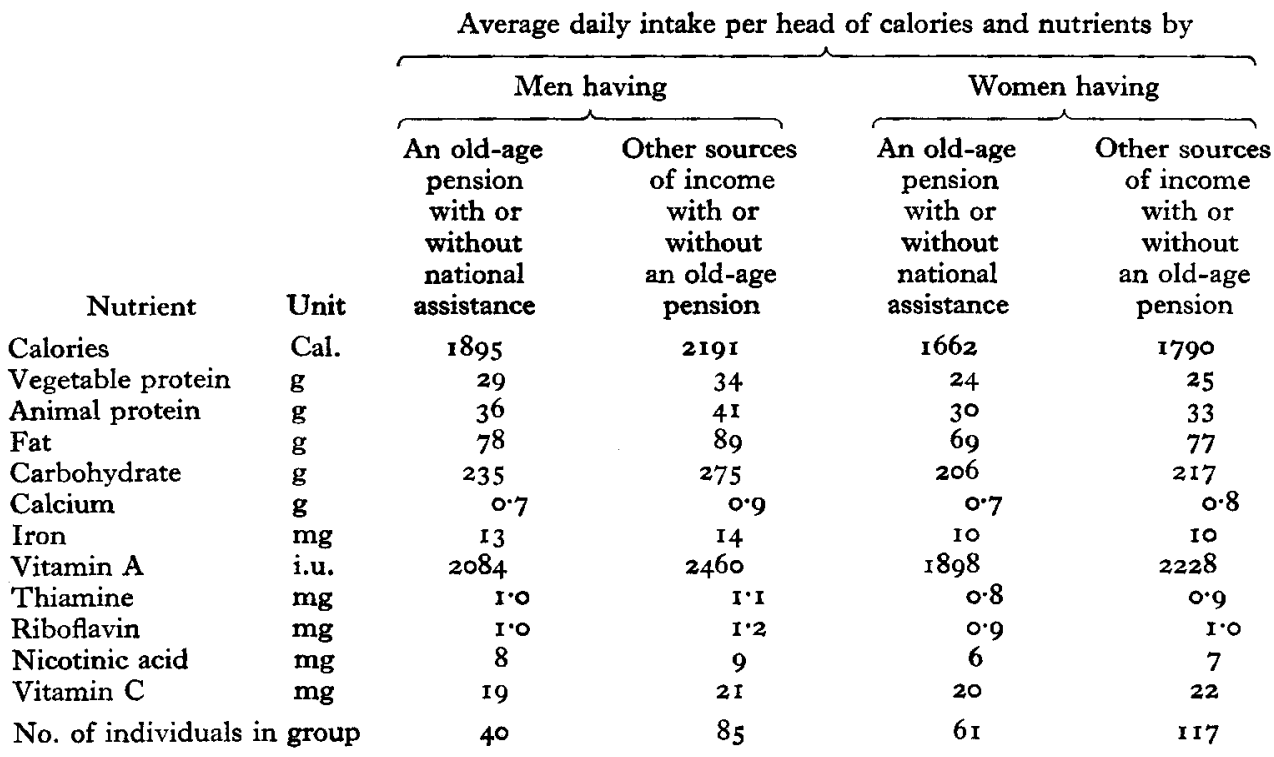

Men up to 74 ate a slightly higher proportion ( $91 \%$ ) of midday meals containing cooked protein than men of 75 and over $(85 \%)$, but the older men made up the difference to some extent by eating more breakfasts with cooked protein. The proportion of records of 'no meals' tended to increase with age; for men of 75 years and over, $12 \%$ of the midday meals and $14 \%$ of the teas and suppers eaten during the survey week were recorded as 'no meal'.

\section{Intake of calories and nutrients at different times of the day}

For the purpose of the analysis the day was divided into three periods:

(I) Morning which included breakfast and midmorning snacks.

(2) Afternoon which included the midday meal and any snacks taken between the midday meal and tea.

(3) Evening which included tea or high tea, supper and any other snacks taken between tea and bedtime. 
Table 17. Proportion of meals of eight different types taken at the different times of the day throughout $\mathrm{I}$ week by the elderly people surveyed

Proportion of meals of different type taken throughout a week by men at

Type of meal*

I. Milk drink alone or with bread

2. Cake alone or with type $I$

3. A cooked protein meal with or without vegetables

4. Type 3 with pudding, cake or bread

5. Cereals alone or with type 1 or type 2

6. Cereals and a cooked protein dish alone or with type $\mathrm{I}$ or type 2

7. Other meals, including salads, puddings or chips alone

8. No meal. A cup of tea is counted as no meal

Total no. of meals (100\%) taken at each time

\begin{tabular}{|c|c|c|c|}
\hline $\begin{array}{c}\text { Breakfast } \\
(\%)\end{array}$ & $\begin{array}{c}\text { Midday } \\
\text { meal } \\
(\%)\end{array}$ & $\begin{array}{c}\text { Tea and } \\
\text { supper } \\
(\%)\end{array}$ & $\begin{array}{c}\text { All } \\
\text { meals } \\
(\%)\end{array}$ \\
\hline 33 & $\mathbf{I}$ & 25 & $2 \mathrm{I}$ \\
\hline 4 & - & 22 & $12\}^{33}$ \\
\hline- & 12 & I & 3 \\
\hline 45 & 77 & $3^{8}$ & 50 \\
\hline I I & - & I & 3 \\
\hline 6 & I & - & 2 \\
\hline- & 2 & I & I \\
\hline I & 7 & 12 & 8 \\
\hline 875 & 875 & $175^{\circ}$ & 3500 \\
\hline
\end{tabular}

\section{'Type of meal*}

I. Milk drink alone or with bread

2. Cake alone or with type I

3. A cooked protein meal with or without vegetables

4. Type 3 with pudding, cake or bread

5. Cereals alone or with type $I$ or type 2

6. Cereals and a cooked protein dish alone or with type 1 or type 2

7. Other meals, including salads, puddings or chips alone

8. No meal. A cup of tea is counted as no meal

Total no. of meals (100\%) taken at each time
Proportion of meals of different type taken throughout a week by women at

\begin{tabular}{|c|c|c|c|}
\hline $\begin{array}{c}\text { Breakfast } \\
(\%)\end{array}$ & $\begin{array}{c}\text { Midday } \\
\text { meal } \\
(\%)\end{array}$ & $\begin{array}{c}\text { Tea and } \\
\text { supper } \\
(\%)\end{array}$ & $\begin{array}{c}\text { All } \\
\text { meals } \\
(\%)\end{array}$ \\
\hline 53 & 4 & 28 & 28) \\
\hline 5 & 4 & 30 & $17\} 45$ \\
\hline- & 12 & 2 & 4 \\
\hline $3 \mathrm{I}$ & 73 & 29 & 40 \\
\hline 6 & - & - & 2 \\
\hline 2 & $\mathbf{I}$ & - & $\mathbf{I}$ \\
\hline 一 & 3 & I & 2 \\
\hline 3 & 3 & 9 & 6 \\
\hline 1246 & 1254 & 2492 & 4992 \\
\hline
\end{tabular}

* The types of meal are more fully set out on p. 173 .

Table $\mathrm{I} 8$ shows the proportions of the daily intake taken at the three different times of the day. There is little to be gained in commenting on Table 18 in detail. Its value is for purposes of comparison with similar data for other persons, so that the changes in the proportions of the intakes at different times of the day at different stages of life can be demonstrated and their significance assessed.

\section{Elderly persons in residential homes}

The ages of the eight men studied were $74,74,74,76,76,77,81$ and 82 , and of the eight women $69,70,70,72,75,79,8 \mathrm{I}$ and 86 . All the subjects were fit. Table 19 shows for men and women the average intake of calories and nutrients and the proportion of the intakes consumed at the different times of day. 
Table 18. Proportion of the average daily intake of calories and nutrients taken at the various times of the day by the elderly people surveyed

\begin{tabular}{|c|c|c|c|c|c|c|}
\hline \multirow[b]{2}{*}{ Nutrient } & \multicolumn{3}{|c|}{$\begin{array}{l}\text { Proportion of average daily consumption } \\
\text { of nutrients taken by men in the }\end{array}$} & \multicolumn{3}{|c|}{$\begin{array}{l}\text { Proportion of average daily consumpti } \\
\text { of nutrients taken by women in the }\end{array}$} \\
\hline & $\begin{array}{l}\text { Morning } \\
(\%)\end{array}$ & $\begin{array}{l}\text { Afternoon } \\
(\%)\end{array}$ & $\begin{array}{l}\text { Evening } \\
(\%)\end{array}$ & $\begin{array}{l}\text { Morning } \\
(\%)\end{array}$ & $\begin{array}{l}\text { Afternoon } \\
(\%)\end{array}$ & $\begin{array}{l}\text { Evening } \\
(\%)\end{array}$ \\
\hline Calories & 28 & 30 & 42 & 27 & 29 & 44 \\
\hline Vegetable protein & 29 & 27 & 44 & 27 & 27 & 46 \\
\hline Animal protein & 21 & 46 & 33 & 19 & 45 & 36 \\
\hline Fat & 28 & 31 & $4 I$ & 27 & 30 & 43 \\
\hline Carbohydrate & 29 & 27 & 44 & 28 & 26 & 46 \\
\hline Calcium & 25 & 25 & 50 & 24 & 24 & 52 \\
\hline Iron & 24 & 42 & 34 & 21 & 44 & 35 \\
\hline Vitamin A & 26 & 33 & 41 & 29 & 28 & 43 \\
\hline Thiamine & 30 & 30 & 40 & 28 & $3 r$ & $4 I$ \\
\hline Riboflavin & 27 & 30 & 43 & 26 & 29 & 45 \\
\hline Nicotinic acid & 22 & 40 & 38 & 20 & $4 I$ & 39 \\
\hline Vitamin C & 12 & 60 & 28 & 17 & $5 I$ & 32 \\
\hline
\end{tabular}

Table 19. Average daily intake per head of calories and nutrients by eight elderly men and eight elderly women in residential homes and the distribution of the intake throughout the day

\begin{tabular}{|c|c|c|c|c|c|c|c|c|c|}
\hline \multirow[b]{3}{*}{ Nutrient } & \multirow[b]{3}{*}{ Unit } & & & \multicolumn{6}{|c|}{ Proportion of the average daily intake taken by } \\
\hline & & \multicolumn{2}{|c|}{$\begin{array}{l}\text { Average daily } \\
\text { intake by }\end{array}$} & \multicolumn{3}{|c|}{ Men in the } & \multicolumn{3}{|c|}{ Women in the } \\
\hline & & Men & Women & $\begin{array}{l}\text { Morning } \\
(\%)\end{array}$ & $\begin{array}{c}\text { Afternoon } \\
(\%)\end{array}$ & $\begin{array}{c}\text { Evening } \\
(\%)\end{array}$ & $\begin{array}{c}\text { Morning } \\
(\%)\end{array}$ & $\begin{array}{c}\text { Afternoon } \\
(\%)\end{array}$ & $\begin{array}{c}\text { Evening } \\
(\%)\end{array}$ \\
\hline Calories & Cal. & 2536 & 2138 & 30 & $3^{I}$ & 39 & 24 & 30 & 46 \\
\hline $\begin{array}{l}\text { Vegetable } \\
\text { protein }\end{array}$ & $\mathrm{g}$ & 36 & 27 & 26 & 36 & 38 & 24 & 36 & $4^{\circ}$ \\
\hline $\begin{array}{l}\text { Animal } \\
\text { protein }\end{array}$ & g & 34 & 33 & 24 & 42 & 34 & 24 & 37 & 39 \\
\hline Fat & $\mathrm{g}$ & 108 & 103 & 35 & 22 & 43 & 22 & 22 & 56 \\
\hline Carbohydrate & $\mathrm{g}$ & $3 \mathrm{II}$ & 244 & 27 & 35 & 38 & 26 & 37 & 37 \\
\hline Calcium & $\mathrm{g}$ & 0.9 & 0.7 & 24 & 32 & 44 & $2 \mathrm{I}$ & 33 & 46 \\
\hline Iron & $\mathrm{mg}$ & 12 & 10 & 24 & 43 & 33 & 23 & 46 & $3 I$ \\
\hline Vitamin A & i.u. & 2339 & 6020 & 35 & 12 & 53 & I6 & 49 & 35 \\
\hline Thiamine & $\mathrm{mg}$ & $I \cdot I$ & 0.9 & 30 & 38 & 32 & 23 & 44 & 33 \\
\hline Vitamin $\mathbf{C}$ & $\mathrm{mg}$ & 26 & 38 & 5 & 83 & 12 & $2 I$ & 66 & 13 \\
\hline
\end{tabular}

Of those living at home who were eligible for the social and food survey $36 \%$ eventually failed to co-operate (Table I). The majority failed because of some physical disability or because they refused and gave up in the course of the survey. The proportion of refusals is relatively high, and probably introduced a bias into the sample, because those who did not co-operate possibly had more disabilities or domestic difficulties than those who did. The results from the survey may, therefore, give somewhat too favourable a picture, at least in regard to domestic and economic circumstances. Moreover, the subjects studied were living alone or with a spouse only, never with relatives or friends. The survey was thus not representative of the elderly as a whole, and the results are not, therefore, directly comparable with those reported by Sheldon (1948). 
The survey suggests that the majority of the elderly living at home managed to cope with their domestic responsibilities reasonably well, with any help they might receive (see p. 164). For two-thirds of them help came from relatives and friends. It is perhaps surprising that about one-third had paid domestic help. There was, however, quite a proportion, about one-fifth, who would have appreciated domestic help. The relatively high proportion of about a quarter who thought they could not get help in an emergency emphasizes the need for vigilance to ensure that in such times the elderly are not neglected. There is little doubt that many of the elderly are living in houses larger than they require. Moreover, the houses are seldom convenient from the domestic viewpoint; stairs have to be climbed, and there is too much to be kept clean.

Current earnings formed part of or all the income of $24 \%$ of the households studied (Table 5). The importance of such earnings is well demonstrated by the amount expended on the different household items at different levels of income. Those with small, unsupplemented incomes had little left over after necessities had been bought (T'able 7).

The present survey provides for the first time data on food consumption and the intake of calories and nutrients for a reasonably large group of elderly persons living at home. Food consumption varied according to sex, age, social class, income level, state of health and whether the subject lived alone or not. The variations were, on the whole, greater for men than for women. As is found in all food surveys, there were large variations between individuals in the intake of calories and nutrients. It was somewhat surprising, however, to find with the daily intakes that six of the 303 subjects had less than rooo Cal., eighteen less than $0.4 \mathrm{~g}$ calcium, eleven less than $6 \mathrm{mg}$ iron, ten less than rooo i.u. vitamin A, twenty-one less than $0.6 \mathrm{mg}$ thiamine, twenty-three less than $0.6 \mathrm{mg}$ riboflavin and fifteen less than $5 \mathrm{mg}$ vitamin $\mathrm{C}$ (Table 12). The possible clinical significance of such low intakes is being examined. It is not possible to say whether the nutrient intakes of the groups studied were satisfactory or not, simply because there are so few data for the elderly. If the requirements of the elderly are the same as those for adults set up by the British Medical Association (1950), the intakes of all nutrients by those classified as fit were satisfactory except for that of vitamin A by women; those moderately fit or unfit may have special dietary needs.

The average calorie intake of the men and women living in residential homes was from 400 to 500 Cal. a day greater than that of those living in their own homes. For a group of twelve active men aged from 60 to 85 years living in an institution, whose diets were weighed for a week, Pyke, Harrison, Holmes \& Chamberlain (1947) found an average intake of 2132 Cal./day, that is about the same as was found for the subjects in the present survey living at home. There are several possible explanations for the difference found in the present survey between the intakes at home and in institutions. It is probably important that the meals were provided to those living in the institutions whereas those in their own homes had the bother of buying, preparing and cooking them. Those in institutions probably led a much less active life than those living at home. It would indeed be interesting to know the true 
significance of the difference in calorie intake of those living in their own homes and those living in institutions.

In $195^{\circ}$ the Food and Agriculture Organization issued a report on calorie requirements in which standards are suggested for the elderly (Food and Agriculture Organization of the United Nations, 1950). They were: 60-69 years, men, 2240, women 1610; 70-79 years, men 2000, women I440; 80 years and over, men 1760, women 1270 . The calorie intakes found in the present survey for the elderly living at home were greater, especially for women, than those suggested by F.A.O. The elderly people in the present survey, as a group, were in no way obese, and it would, therefore, seem probable that the standards suggested by F.A.O. are too low.

\section{SUMMARY}

I. A social and food survey of elderly men and women was made in Sheffield between January $195^{\circ}$ and March $195^{I}$ as part of a more comprehensive health survey. The survey was restricted to men and women living alone or as married couples without any other person.

2. Of the 303 subjects surveyed 125 were men aged at least 67 , and $\mathrm{r}_{78}$ were women aged at least 62 .

3. The 303 subjects represented $64 \%$ of those who were eligible according to the terms of the survey. The loss of $36 \%$ of the sample was somewhat high and may have introduced a bias into the results.

4. Information of three kinds was collected from each individual for a period of I week on (I) social and domestic circumstances, (2) economic circumstances, (3) food consumption.

5. Houses of the two-storey type were occupied by $91 \%$ of the subjects. Many of them had more room than they needed; well over half of those living alone had four or more habitable rooms. Most of the rents were between $5^{s}$. and $15^{s}$. a week.

6. Help with shopping or housework was obtained by $45 \%$ of those living alone and $33 \%$ of those living as married couples. Of those living alone or as married couples, $27 \%$ thought they would not be able to get help in times of sickness or emergency.

7. Thirty-eight of the subjects were still at work; seventeen of them were women. Earnings ranged from $£_{1}$ to $£ 7$ a week. If account is taken of the employment of the husband or the wife of the subject, current earnings formed part of the income of $24 \%$.

8. The average income was $39 s$. $7 d$. per head a week. It was 4 Is. $8 d$. for those living alone and 39 s. for those living as married couples. $43 \%$ of those living alone and $54 \%$ of those living as married couples had incomes of less than 35 s. a week.

9. The average expenditure on food was ${ }_{15} \mathrm{~s}$. a week for those living as married couples and $\mathrm{r}_{7}$ s. $2 d$. for those living alone.* The expenditure on food increased substantially with increasing income. The amount of money left over weekly after expenditure on rent, food, drink, tobacco and fuel ranged according to income from

* The figures refer to those who gave information on all the items included. 
Is. $7 d$. to $32 s$. $6 d$. for those living as married couples, and from $5 d$. to $35 s$. $5 d$. for those living alone.

Io. The consumption of particular foods varied with different social and economic factors, such as age, sex, state of health, social status and income, and according to whether the subject was living alone or as a married couple. The variations were more marked for men than for women.

II. The average daily intake of calories was: up to 69 years, 2126 Cal. for men, I8I I for women; 70-74 years 2154 for men, 1700 for women; 75 years and over, 2006 for men and 1588 for women. The protein intake averaged $7 \mathrm{I} \mathrm{g}$ for men and $57 \mathrm{~g}$ for women. The daily intake of six of the 303 subjects was less than $1000 \mathrm{Cal}$,, of eighteen less than $0.4 \mathrm{~g}$ calcium, of eleven less than $6 \mathrm{mg}$ iron, of ten less than I000 i.u. vitamin $\mathrm{A}$, of twenty-one less than $0.6 \mathrm{mg}$ thiamine, of twenty-three less than $0.6 \mathrm{mg}$ riboflavin and of fifteen less than $5 \mathrm{mg}$ vitamin C.

12. A survey was made for I week of the diets of eight elderly men and eight elderly women living in residential institutions. The calorie intakes averaged 2536 Cal. a day for men and 2138 for women.

13. Comparison of the calorie intakes found in the survey with the standard intakes recently recommended for elderly people by the Food and Agriculture Organization suggests that those standards are too low for the elderly population of the United Kingdom.

As has already been stated, the present social and food survey was part of a more comprehensive health survey made under the aegis of Professor W. Hobson of the Department of Social and Industrial Medicine of the University of Sheffield. Acknowledgement is made to all who took part in that survey and who directly or indirectly assisted in the present study. Particular thanks are due to Professor W. Hobson, Dr John Pemberton, Dr H. Droller and Mr D. L. Woodhouse for their interest and assistance at every stage of the work.

\section{REFERENCES}

Accessory Food Factors Committee (1945). M.R.C. (War) Memor. no. 14.

Beltram, A. \& Bransby, E. R. (1950). Mon. Bull. Minist. Hlth Lab. Serv. 9, 177.

British Medical Association (1950). Report of the Committee on Nutrition. London: British Medical Association.

Food and Agriculture Organization of the United Nations (1950). Nutritional Studies no. 5. Washington D.C.: Food and Agriculture Organization of the United Nations.

Great Britain: Registrar General (1951). Classification of Occupations, 1950. London: H.M. Stationery Office.

Greenlees, A. \& Adams, J. (1950). Old People in Sheffield. Sheffield: Sheffield Council of Social Service.

McCance, R. A. \& Widdowson, E. M. (1946). Spec. Rep. Ser. med. Res. Coun., Lond., no. 235, 2nd ed.

Pyke, M., Harrison, R., Holmes, S. \& Chamberlain, K. (1947). Lancet, 253, 46r.

Sheldon, J. H. (1948). The Social Medicine of Old Age. Oxford: University Press.

Widdowson, E. M. (1936). Ұ. Hyg., Camb., 36, 269. 